\title{
The effect of different surface roughnesses on the differentiation of MC3T3-E1 mouse osteoblasts in vitro
}

\author{
Kiyoto Takemoto $^{1}$, Kenichi Matsuzaka ${ }^{2,3}$, Masaki Shimono ${ }^{1}$, Masao Yoshinari ${ }^{3}$, Takashi Inoue ${ }^{2,3}$ \\ ${ }^{1}$ Department of Pathology, Tokyo Dental College, Chiba, Japan \\ ${ }^{2}$ Oral Health Science Center hrc7, Tokyo Dental College, Chiba, Japan \\ ${ }^{3}$ Department of Clinical Pathophysiology, Tokyo Dental College, Chiba, Japan
}

Abstract:

Background: The purpose of this study was to investigate the differentiation and maturation of osteoblasts on surfaces with different roughnesses.

Methods: Blasting a culture dish surface with $\mathrm{Al}_{2} \mathrm{O}_{3}$ particles of $25 \mu \mathrm{m}, 50 \mu \mathrm{m}$ or 180 $\mu \mathrm{m}$ diameter produces mean surface a roughness $(\mathrm{Ra})$ of $0.48 \pm 0.07,1.02 \pm 0.14$ or $3.10 \pm 0.36$, respectively. Morphological changes of cells were compared, and the expression of mRNAs of osteopontin and osteocalcin were evaluated. Further, the ratio of alizarin red positive area was calculated.

Results: Cells cultured on the $180 \mu \mathrm{m}$ blasted surface had almost the same morphology as those cultured on the $50 \mu \mathrm{m}$ blasted surface; however, cellular bridges tended to be much wider and more spread out. The expressions of osteopontin and osteocalcin mRNAs in cells cultured on the $180 \mu \mathrm{m}$ blasted surface have greater up-regulation than the other cells. Further, the ratio of alizarin red positive area in $180 \mu \mathrm{m}$ blasted surface was significantly higher than those of others.

Conclusions: These results suggest that the $180 \mu \mathrm{m}$ blasted surface, with a surface roughness of approximately $3 \mu \mathrm{m}$ in width, is the best surface for MC3T3-E1 cells to differentiate and mature in vitro.

[Oral Med Pathol 2010; 15: 45-51 doi: 10.3353/omp.15.45]

Key words: surface geometry, osteoblast, SEM, mRNA expressionm

Correspondence: Kenichi Matsuzaka, Oral Health Science Center hrc7 Department of Clinical Pathophysiology, Tokyo Dental College, 1-2-2 Masago, Mihama-ku, Chiba 261-8502 Japan

Phone: 81-43-270-3581, Fax: 81-43-270-3583,E-mail: matsuzak@tdc.ac.jp

\section{Introduction}

Many studies have compared the influence of surface geometry and the characteristics of dental implants on cell behavior using in vivo and in vitro model systems (1-18). Dental implant surface characteristics can markedly influence cell attachment, orientation and subsequent osseointegration in situ. In particular, osteoblastic cell differentiation and maturation around titanium dental implants have been widely studied $(4,13,15,19)$. Those studies show that titanium implant surfaces may modulate the phenotypic expression and metabolism of osteoblastic cells $(2,20)$. However, published studies on the biological effects of surface properties on osteoblastic cell differentiation and maturation do not reveal whether different surfaces are more suitable than others.

Differentiation toward an osteoblastic phenotype is a multi-step process which is regulated by several factors, such as hormones and growth factors (21) and also by surface geometry (14). The morphological changes undergone by cells during attachment and flattening onto a matrix surface have been described by Taylor (17). In Taylor's model, the cells adhere to the substratum and progressively flatten on the substrate. These changes in cell morphology are also related to cell differentiation in terms of their function as mechanoreceptors, and in terms of the pathway which might link the nucleus to activate the proper osteoblastic gene, such as osteopontin (OPN) or osteocalcin (OCN).

In cell cultures, it is difficult to recognize the differentiation and maturation of cells using only morphological change as a criterion. The study of mRNA expression has recently developed as a useful tool to investigate weak cell signals. To detect the weak signal of OPN, which is known to be related to osteogenesis, and OCN, which is known to be related to calcification, the reverse transcription polymerase chain reaction (RT-PCR) method is quite useful.

In this study, the morphology of cells attached to different surfaces created by blasting with different sized 
$\mathrm{Al}_{2} \mathrm{O}_{3}$ particles was investigated using scanning electron microscopy (SEM). Furthermore, the expression of mRNAs encoding 2 bone related proteins, OPN and OCN, was also evaluated using RT-PCR.

\section{Materials and methods}

\section{Surface preparation by blasting}

Cells surrounding dental implants include fibroblasts and osteoblasts, whose cell sizes are known to be 20 to 50 $\mu \mathrm{m}$. Furthermore, osteoclasts are multinucleated giant cells, with a diameter ranging anywhere from 100 to $200 \mu \mathrm{m}$. Accordingly, the substrates used in this study had three different kinds of surface roughness. The internal surfaces of culture dishes were blasted with $\mathrm{Al}_{2} \mathrm{O}_{3}$ (aluminum oxide), with grain sizes of $25 \mu \mathrm{m}, 50 \mu \mathrm{m}$, or $180 \mu \mathrm{m}$ diameter, at a pressure of 0.5 $\mathrm{MPa}$. Each surface roughness was then characterized using a profilometer (Handysurf E-30A, Tokyo Seimitsu, Tokyo). Measurements were done on 3 randomly selected fields of each sample, and the mean surface roughness $(\mathrm{Ra})$, the maximum surface roughness $(\mathrm{Rmax})$ and the spacing between the peaks $(\mathrm{Sm})$ were calculated. Untreated $35 \mathrm{~mm}$ culture dishes were used as controls.

\section{Preparation of cell suspensions}

MC3T3-E1 osteoblast-like cells derived from mice (Riken, Tokyo, Japan) were cultured with $\alpha$-MEM (minimum essential medium, Gibco, Carlsbad, CA, USA) with $10 \%$ fetal calf serum supplemented $10,000 \mathrm{M} / \mathrm{ml}$ penicillin $\mathrm{G}$ and $10,000 \mu \mathrm{g} / \mathrm{ml}$ streptomycin sulfate. Furthermore, $10^{-8} \mathrm{M}$ dexamethasone and $10 \mathrm{mM} \beta$-glycerophosphate were added to the medium. Cells were cultured in $5 \%(\mathrm{v} / \mathrm{v})$ carbon dioxide $\left(\mathrm{CO}_{2}\right)$ at $37^{\circ} \mathrm{C}$ for 5 days until they were confluent, with changes of medium every $48 \mathrm{hrs}$. Cells were observed every day by phase-contrast microscopy. When the cells became confluent, they were detached from the flasks using $0.1 \%$ trypsin. The cell number in each suspension was determined and adjusted to $2 \times 10^{4}$ cells $/ \mathrm{ml}$ in the same culture medium. Approximately $4 \times 10^{5}$ cells in $5 \mathrm{ml}$ media were seeded on each different surface of culture dish described above. After $12 \mathrm{hrs}$ incubation at $37^{\circ} \mathrm{C}$, the cells were washed with phosphate-buffered saline (PBS) to remove any unattached cells.

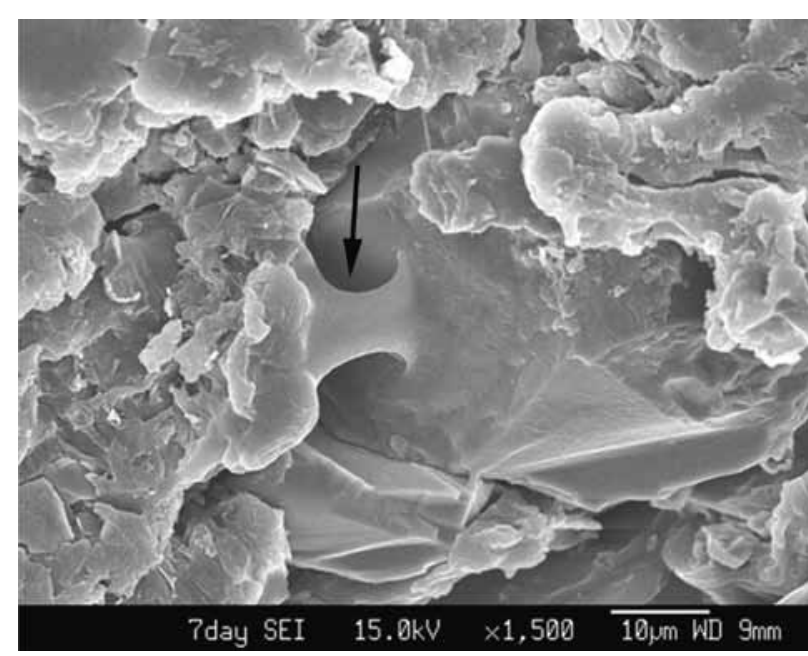

Fig. 1. Scanning electron microscopy (SEM) image about the proportion of area of cellular bridge (PACB). The PACB (arrow) in the whole cell area was calculated on the SEM image.

\section{Scanning electron microscopic evaluation of cells}

Cells cultured on each surface were fixed with $2.5 \%$ glutaraldehyde in $0.1 \mathrm{mM}$ sodium cacodylate buffer $(\mathrm{pH}$ 7.2), at 3, 7 and 10 days of culture. Cells were washed with PBS, and then dehydrated in graded ethanols and critical point-dried from liquid $\mathrm{CO}_{2}$ using a critical point-drier. Samples were sputter coated with gold for $2 \mathrm{~min}$ and were viewed using a HITACHI 8000 SEM.

The proportion of area of cellular bridge (PACB) in the whole cell area was calculated on the SEM image (Fig.1),

$$
\operatorname{PACB}(\%)=\frac{\text { area of cellular bridge }}{\text { all area of cells }} \times 100
$$

\section{RT-PCR}

Total RNAs were extracted using the Isogen reagent (Nippon Gene, Toyama, Japan) according to the manufacturer's instructions. Briefly, cultured osteoblast-like cells were homogenized and solubilized in an Isogen/ chloroform solution at $4^{\circ} \mathrm{C}$. Supernatants were obtained by centrifugation at $12,000 \times \mathrm{g}$ for $20 \mathrm{~min}$ at $4^{\circ} \mathrm{C}$. The precipitates were obtained by decantation and were washed with $75 \%$ ethanol. Finally, the RNA pellets were dissolved in RNAase-free water and stored at $-20^{\circ} \mathrm{C}$ until used. Using the extracted RNA as a template, reverse transcription reactions were carried out with an RT-PCR kit (RNA PCR

Table 1. PCR primers used for PCR analysis

\begin{tabular}{lllc}
\hline Target cDNA & \multicolumn{1}{c}{ Primer sequence } & PCR condition (cycle anealing) & Product size \\
\hline \multirow{2}{*}{ osteopontin } & Forward (5'-CTC GGA GGA GAA GGC GCA TTA -3') & 45 cycles, $95^{\circ} \mathrm{C}(10 \mathrm{~s}), 66^{\circ} \mathrm{C}(10 \mathrm{~s}), 72^{\circ} \mathrm{C}(10 \mathrm{~s})$ & $207 \mathrm{bp}$ \\
& Reverse (5'- CCA TCG TCA TCG TCG TCG TCA -3') & & \\
\multirow{2}{*}{ osteocalcin } & Forward (5'-GGT GCA AAG CCC AGC GAC TCT -3') & 45 cycles, 95 ${ }^{\circ} \mathrm{C}(10 \mathrm{~s}), 56^{\circ} \mathrm{C}(5 \mathrm{~s}), 72^{\circ} \mathrm{C}(9 \mathrm{~s})$ & $199 \mathrm{bp}$ \\
& Reverse (5'-GGA AGC CAA TGT GGT CCG CTA -3') & & \\
\multirow{2}{*}{ GAPDH } & Forward (5'-TGAACGGGAAGCTCACTGG-3') & 40 cycles, $95^{\circ} \mathrm{C}(10 \mathrm{~s}), 60^{\circ} \mathrm{C}(10 \mathrm{~s}), 72^{\circ} \mathrm{C}(12 \mathrm{~s})$ & $307 \mathrm{bp}$ \\
\hline
\end{tabular}


Table 2. Surface roughness produced by blasting a smooth culture dish surface with $\mathrm{AL}_{2} \mathrm{O}_{3}$ particles

\begin{tabular}{ccccc}
\hline \multicolumn{2}{c}{ particle size } & mean surface roughness $(\mu \mathrm{m})$ & maxim surface roughness $(\mu \mathrm{m})$ & spacing between the peaks $(\mu \mathrm{m})$ \\
\hline \multirow{2}{*}{$25 \mu \mathrm{m}$} & AV & 0.48 & 5.82 & 23.4 \\
& SD & 0.07 & 1.3 & 2.62 \\
\multirow{2}{*}{$50 \mu \mathrm{m}$} & AV & 1.02 & 9.58 & 37.9 \\
& SD & 0.14 & 0.9 & 6.3 \\
\multirow{2}{*}{$180 \mu \mathrm{m}$} & AV & 3.1 & 28.9 & 57.1 \\
& SD & 0.36 & 5.41 & 6.42 \\
\hline
\end{tabular}

kit ver 2.1, Takara Bio Inc., Kyoto, Japan) to synthesize cDNA. PCR was then carried out for 35 cycles using OPN and OCN primers (Table 1). PCR products were separated on $2 \%$ agarose ethidium bromide gels. Data were normalized using the ratio of sample data to that of the housekeeping gene glucose-6-phosphate dehydrogenase (GAPDH). After normalization, mRNA levels were expressed relative to GAPDH.

To determine mRNA levels, a quantitative RT-PCR assay was conducted using a LightCycler with the doublestranded DNA dye SYBR Green I (F. Hoffmann-La Roche Ltd, Basel, Switzerland). The primers used for the LightCycler assays were the same as those used for ordinary RT-PCR. Quantification was performed by comparing the levels obtained to standardized samples. In the present study, the concentrations of cDNA in unstimulated samples were $0.2,0.5,1.0$ and $2.0 \mu \mathrm{l}$. The PCR conditions used in the LightCycler are 40 cycles $\left(95^{\circ} \mathrm{C} 10 \mathrm{sec}, 60^{\circ} \mathrm{C} 5 \mathrm{sec}, 72^{\circ} \mathrm{C} 12\right.$ $\mathrm{sec})$. Melting curve analysis was also performed after the PCR amplification to confirm the absence of the primer dimer in the PCR products.

\section{Alizarin red staining and ratio of positive area}

Cells cultured on each surface were fixed with $10 \%$ formalin after 2 weeks of culture. Cells were washed with PBS and then immersed in $1 \%$ alizarin red solution $(\mathrm{pH} 7.0$, sodium alizarin sulfonate, Wako Pure Chemical Industries, Ltd., Osaka, Japan). Then the ratios of alizarin red positive areas were calculated.

\section{Statistical analysis}

The results were analyzed via one-way ANOVA and were then compared by the Scheffe's test. The level of significance was 0.05 and 0.01 in these tests.

\section{Results}

\section{Surface roughness}

Blasting a smooth culture dish surface with $\mathrm{Al}_{2} \mathrm{O}_{3}$ particles of $25 \mu \mathrm{m}, 50 \mu \mathrm{m}$ or $180 \mu \mathrm{m}$ diameter produced a mean surface roughness $(\mathrm{Ra})$ of $0.48 \pm 0.07 \mu \mathrm{m}, 1.02 \pm 0.14$ $\mu \mathrm{m}$ or $3.10 \pm 0.36 \mu \mathrm{m}$, respectively; a maximum surface roughnesses (Rt) of $5.82 \pm 1.30 \mu \mathrm{m}, 9.58 \pm 0.90 \mu \mathrm{m}$ or 28.90 $\pm 5.41 \mu \mathrm{m}$, respectively; and a spacing between peaks (Sm) of $23.40 \pm 2.62 \mu \mathrm{m}, 37.90 \pm 6.30 \mu \mathrm{m}$ or $57.10 \pm 6.42 \mu \mathrm{m}$, respectively (Table 2 ). These surfaces were observed to be hollow with specific dimensions and shapes. Fig. 1 shows the SEM pictures of blasted culture dishes.

\section{Cell morphology on different surface roughnesses}

Cells cultured on untreated $35 \mathrm{~mm}$ culture dishes were characterized as spindle-shaped with many microspikes at all time periods (Fig. 2). Cells cultured on the $25 \mu \mathrm{m}$ blasted surface were spindle-shaped at day 3 , and were spread out with processes at days 7 and 10 . The cells had adapted to the underlying topography at all time periods (Figs. 3 a-c). Cells cultured on the $50 \mu \mathrm{m}$ blasted surface grew deep into the hollows and had attached with spikes to the substrate. Slender cell bridges were frequently observed at day 3 .

The cells were scattered widely and had attached to the substrate with processes at days 7 and 10 (Figs. 3 d-f).

At day 10, the cells had adapted to the underlying topography. Cells cultured on the $180 \mu \mathrm{m}$ blasted surface made much wider cellular bridges than did cells cultured on the $50 \mu \mathrm{m}$ blasted surface, and had multiple points of attachment to the substrate at all time periods (Figs. 3 g-i). At day 10 , the cells had adapted to the underlying topography.

\section{Proportion of area of cellular bridge (PACB)}

PACB on the $25 \mu \mathrm{m}$ surface was the lowest and on the $180 \mu \mathrm{m}$ surface was the highest at any of the time periods with a significant difference $(P<0.01)$. PACB on the $50 \mu \mathrm{m}$ surface was just between $25 \mu \mathrm{m}$ and $180 \mu \mathrm{m}$ without significant difference (Fig. 4).

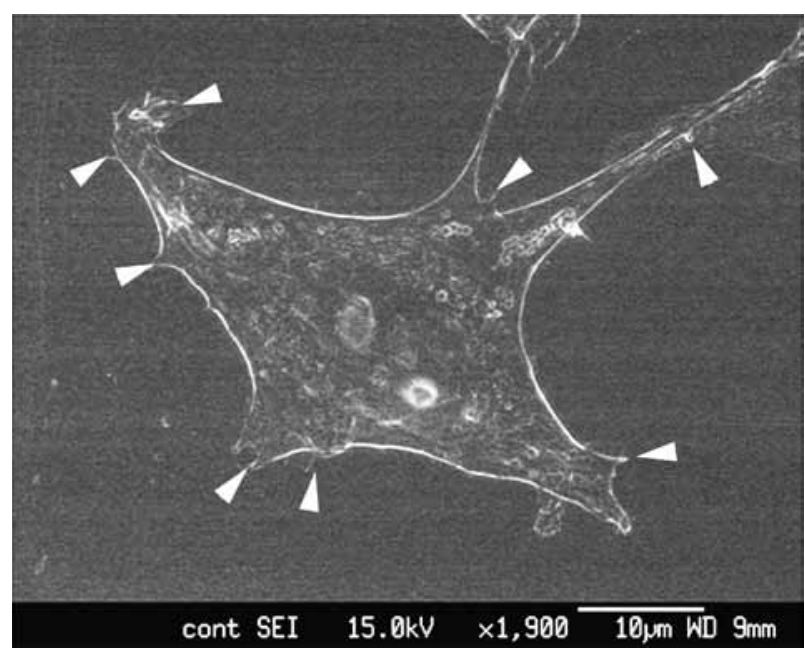

Fig. 2. SEM image of MC3T3-E1 cells on smooth surface. Arrowheads show cells attatching to the surface. 

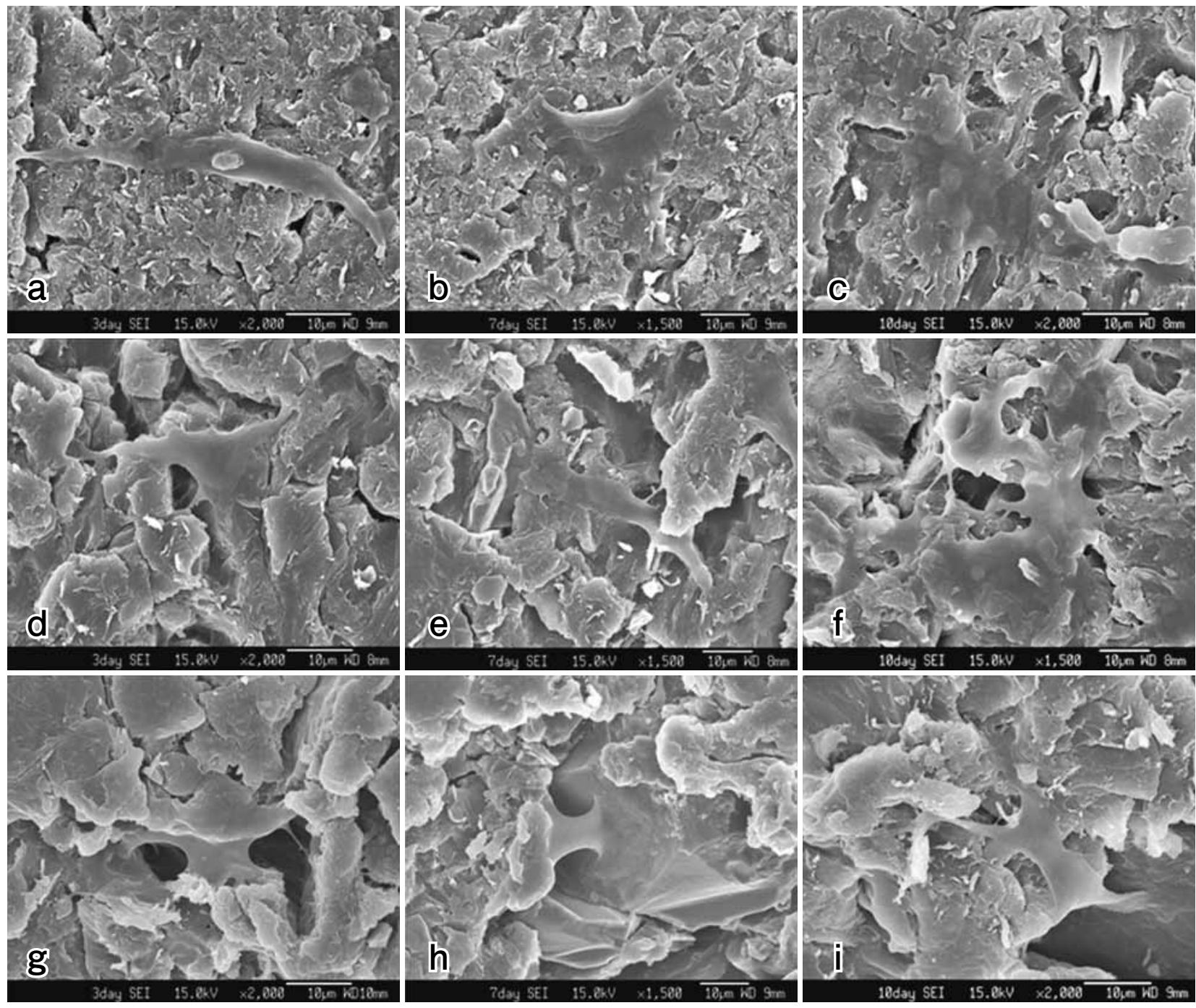

Fig. 3. SEM images of MC3T3-E1 cells. (a) 3 days on $25 \mu \mathrm{m}$ blasted surface; (b) 7 days on $25 \mu \mathrm{m}$ blasted surface; (c) 10 days on 25 $\mu \mathrm{m}$ blasted surface; (d) 3 days on $50 \mu \mathrm{m}$ blasted surface; (e) 7 days on $50 \mu \mathrm{m}$ blasted surface; (f) 10 days on $50 \mu \mathrm{m}$ blasted surface; (g) 3 days on $180 \mu \mathrm{m}$ blasted surface; (h) 7 days on $180 \mu \mathrm{m}$ blasted surface; (i) 10 days on $180 \mu \mathrm{m}$ blasted surface. On the $25 \mu \mathrm{m}$ blasted surface, cells had adapted to the underlying topography during the experimental period (a-c). On the $50 \mu \mathrm{m}$ blasted surface, cells grew deep into the hollows, and were widely spread and had attached to the substrate with processes at days 7 and $10(\mathrm{~d}-\mathrm{f})$. On the $180 \mu \mathrm{m}$ blasted surface, cells make a much wider cellular bridges (g-i).

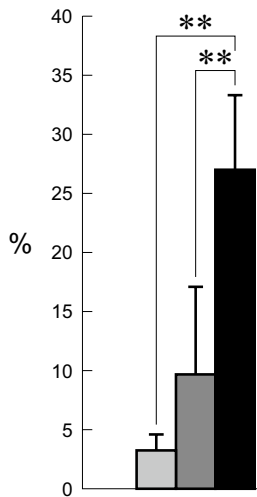

3 days

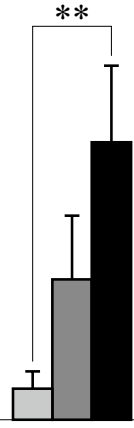

7 days

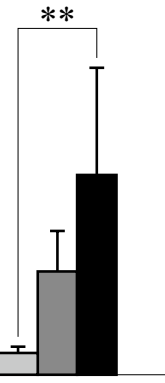

10 days

Fig. 4. The proportion of PACB areas in MC3T3-E1 cells cultured on different surface conditions. $\square, 25 \mu \mathrm{m}$ surface; $\square, 50 \mu \mathrm{m}$ surface; $\square, 180 \mu \mathrm{m}$ surface. PACB on the $25 \mu \mathrm{m}$ surface was the lowest and on $180 \mu \mathrm{m}$ surface was the highest at any of the time periods with significant difference $(P<0.01)$. PACB on the $50 \mu \mathrm{m}$ surface was just between $25 \mu \mathrm{m}$ and $180 \mu \mathrm{m}$ without significant difference.

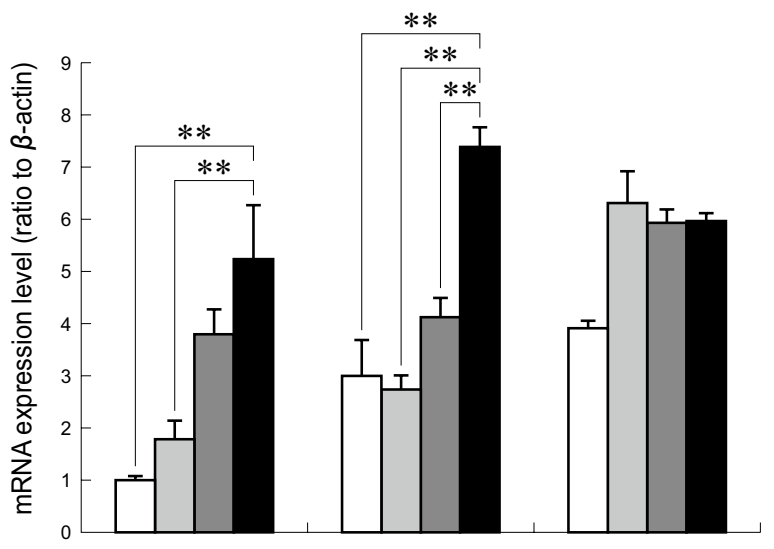

3 days

7 days

10 days

Fig. 5. Expression of osteopontin mRNA in MC3T3-E1 cells cultured on different surface conditions. $\square$, control; $\square$, $25 \mu \mathrm{m}$ surface; $\square, 50 \mu \mathrm{m}$ surface; $\square, 180 \mu \mathrm{m}$ surface. Expression of OPN/GAPDH mRNA ratio in cells cultured on the $180 \mu \mathrm{m}$ blasted surface show higher upregulation compared to those of control and $25 \mu \mathrm{m}$ blasted surfaces at day $3(P<0.01)$ and all others at day $7(P<0.01)$. However, there was no significant difference among any of the groups at day $10 .(* * P<0.01)$ 


\section{Expression of mRNAs}

Expression of OPN mRNA in cells cultured on the $180 \mu \mathrm{m}$ blasted surface had higher up-regulation compared to that in cells cultured on the control and the $25 \mu \mathrm{m}$ blasted surfaces at day $3(P<0.01)$ and all others at day $7(P<0.01)$. However, there was no significant difference among any of the groups at day 10 (Fig. 5).

Expression levels of OCN mRNA in cells cultured on the $180 \mu \mathrm{m}$ blasted surface had higher up-regulation compared to those in control cells at day $3 \quad(P<0.05)$. However, there was no significant difference among any of the groups at days 7 or 10 (Fig. 6).

\section{The ratio of alizarin red staining positive area}

The ratio of alizarin red staining positive area was significantly higher for the $180 \mu \mathrm{m}$ blasted surfaces than for those of the control, $25 \mu \mathrm{m}$ and $50 \mu \mathrm{m}$ blasted surfaces (Fig. 7).

\section{Discussion}

The method used in this study was similar to a technique previously described, which compared initial cellular responses to implants of different surface characteristics (5$6)$. Several studies $(12,14)$ have described sequential morphologic changes of osteoblast-like cells as a function of time and have provided detailed descriptions of cellular morphology. However, few studies have investigated osteogenic cellular differentiation and maturation in terms of morphology and expression of mRNAs encoding bone related proteins.

Matsuzaka et al. (11) reported that microgrooves could control osteogenic cell orientation and differentiation and could enhance the production of mineralized matrix in vitro. They examined different sizes of microgrooves and found better cell orientation on microgrooves $1 \mu \mathrm{m}$ to $2 \mu \mathrm{m}$ in width and detected accelerated calcification. However, cells cultured on wider microgrooves of either $5 \mu \mathrm{m}$ or $10 \mu \mathrm{m}$ in width attached to the substrate just the same as on smooth surfaces, and there was no acceleration of calcification. Loesberg et al. $(9,10)$ used the same size microgrooves as Matsuzaka et al. (11) and suggested that cell differentiation was accelerated on microgrooves of $1 \mu \mathrm{m}$ to $2 \mu \mathrm{m}$ in width, because cells were suspended in the groove as a cellular bridge and exposed receptors existing on the cell membrane, making it easier to get molecular signals such as dexamethasone into the culture medium and cause (or induce) the cells to differentiate into mature osteoblasts.

In this study, we blasted culture dish surfaces with $\mathrm{Al}_{2} \mathrm{O}_{3}$ particles of $25 \mu \mathrm{m}$ or $50 \mu \mathrm{m}$ diameter to produce mean surface roughnesses $(\mathrm{Ra})$ of $0.48 \pm 0.07$ or $1.02 \pm 0.14$, respectively. The expressions of mRNAs encoding 2 bone related proteins (OCN and OPN) had not up-regulated compared to those of the control group in this study.

Those surface roughnesses were not significantly different from the untreated surface and might not be effective to induce differentiation. However, the $180 \mu \mathrm{m}$ blasted surface produced a mean surface roughness ( $\mathrm{Ra}$ ) of $3.10 \pm 0.36$ which was wider than the 1 to $2 \mu \mathrm{m}$ microgrooves described above, but the effect was just the same as those microgrooves. However, the cells adapted to the underlying topography at later time periods even on the $180 \mu \mathrm{m}$ blasted surface without making cellular bridges. This might be the reason why the expression of bone-related protein mRNAs had up-regulated at early time periods, but not at late time periods.

OPN is an Arg-Gly-Asp-containing noncollagenous bone protein whose mRNA is found during the stages of bone formation and bone remodeling (22). OPN has been hypothesized to be not only an osteoblast-associated gene, but also a multifunctional cy tokine that generates intracellular signals produced by various bone-related cells and other

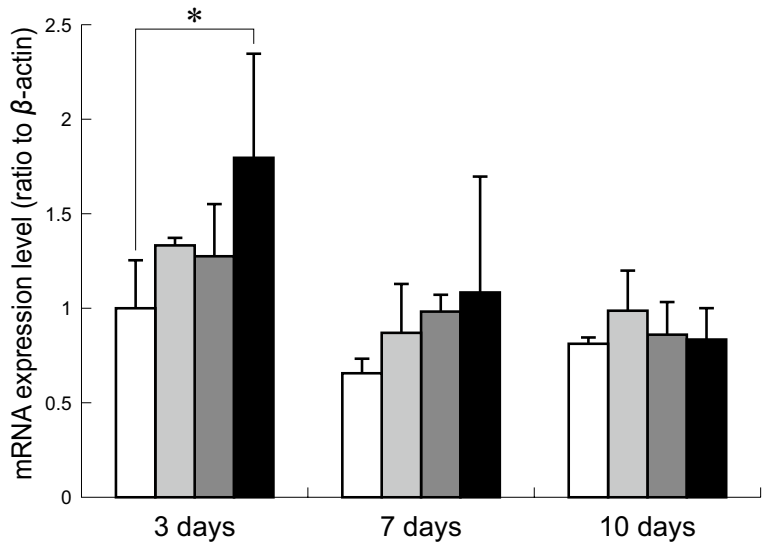

Fig. 6. Expression of osteocalcin mRNA in MC3T3-E1 cells cultured on different surface conditions. $\square$, control; $\square$, $25 \mu \mathrm{m}$ surface; $\square, 50 \mu \mathrm{m}$ surface; $\square, 180 \mu \mathrm{m}$ surface. Expression levels of OCN/GAPDH mRNA ratio in cells cultured on the $180 \mu \mathrm{m}$ blasted surface show higher upregulation compared to those of controls at day $3(P$ $<0.05)$. However, there was no significant difference among any of the groups at days 7 or $10(* P<0.05)$.

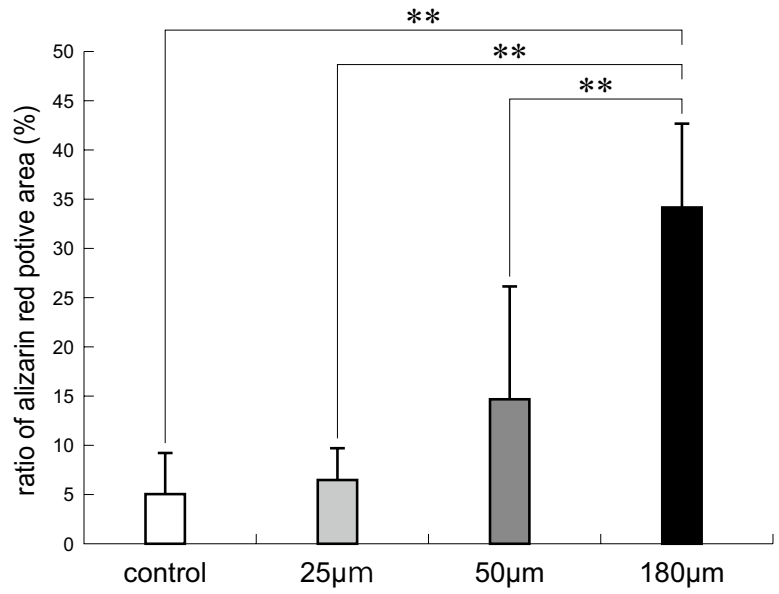

Fig. 7. The ratio of alizarin red staining positive area in MC3T3-E1 cells cultured on different surface conditions. $\square$, control; $\square, 25 \mu \mathrm{m}$ surface; $\square, 50 \mu \mathrm{m}$ surface;, $180 \mu \mathrm{m}$ surface. The ratio of positive area in $180 \mu \mathrm{m}$ blasted surface was significantly higher than those on the control, $25 \mu \mathrm{m}$, and $50 \mu \mathrm{m}$ blasted surfaces $(* * P<0.01)$. 
sorts of cells (11). Toma et al. (23) demonstrated that OPN produced by osteoblasts plays a role in the mechanosignal transduction that requires microfilament structures for signal transduction, and this possibly depends on a protein kinase A-like kinase. OCN is produced only by osteoblasts and has an affinity for bone mineral constituents (24) which implies a role in mineralization of the bone matrix during final osteoblast differentiation (11). Furthermore, the OCN gene has an activator protein-1 (AP-1) binding site (25), and AP-1 (including the c-fos gene transcription complex) is known to be a strong regulator of osteoblastic proliferation and differentiation. Down-regulation of OCN probably reduces c-fos levels, which would also suppress bone formation. Thus, the higher expression of both OPN and OCN at early time periods in cells cultured on the $180 \mu \mathrm{m}$ blasted surface suggests that the $3 \mu \mathrm{m} \mathrm{Sa}$ is a critical size for MC3T3-E1 cells in terms of differentiation and maturation for bone producing cells. On the other hand, it is well known that alizarin red staining can be detected mineralized tissue. In our study, the ratio of alizarin red staining positive area for the $180 \mu \mathrm{m}$ blasted surface was higher than for the others. This also indicated that the $180 \mu \mathrm{m}$ blasted surface causes MC3T3-E1 cells to be differentiated and to mature.

Salter et al. demonstrated that integrins, which link components of the extracellular matrix with actin in the cytoplasm, function as mechanoreceptors (26), and Tanaka suggested that this pathway might link the nucleus to mechano-transduction (27). It is known that mechanical force, including microgravity at areas of cellular bridges because of surface geometry, affects cellular morphology as a result of changes in actin filament arrangement and promotes cellular differentiation due to the mechanotransduction, as described above. In this study, the surface roughness created by larger particles, such as ones that are $180 \mu \mathrm{m}$ in diameter, possibly affects the structural pathway. However, the maximum surface roughnesses (Rt) were 5.82 $\pm 1.30,9.58 \pm 0.90$, and $28.90 \pm 5.41$, and the spacings between the peaks $(\mathrm{Sm})$ were $23.40 \pm 2.62,37.90 \pm 6.30$ and $57.10 \pm 6.42$.

These huge sizes of Rt and Sm are too large for the cells and probably are not effective to induce cell differentiation.

Taken together, cells cultured on the $180 \mu \mathrm{m}$ blasted surface demonstrate that a $3 \mu \mathrm{m}$ Sa in width is a critical size to induce MC3T3-E1 cells to differentiate and mature into osteoblasts. This probably results from both mechanotransduction of intranuclear genes and exposure of surface receptors for hormones, such as dexamethasone.

In conclusion, the surface roughness created by blasting using $180 \mu \mathrm{m} \mathrm{Al}_{2} \mathrm{O}_{3}$ seems an appropriate surface for MC3T3-E1 cells to differentiate in early stage in vitro.

\section{Acknowledgments}

The authors would like to thank Ms. Saori Takano for her technical assistance. This research was supported by an Oral Health Science Center Grant HRC7 from the Tokyo Dental College, and by a "High-Tech Research Center" Project for Private Universities: matching fund subsidy from
MEXT (Ministry of Education, Culture, Sports, Science and Technology) of Japan, 2006-2010.

\section{References}

1. Bowers KT, Keller JC, Randolph BA, Wick DG, Michaels CM. Optimization of surface micromorphology for enhanced osteoblast responses in vitro. Int $J$ Oral Maxillofac Implants 1992; 7: 302-10.

2. Brunette DM. The effect of implant surface topography on the behavior of cells. Int J Oral Maxillofac Implants 1988; 3: 231-46.

3. Chang Y-L, Stanford CM, Wefel JS, Keller JC. Osteoblastic cell attachment to hydroxyapatite-coated implant surfaces in vitro. Int J Oral Maxillofac Implants 1999; 14: 239-47.

4. Davies JE. Mechanism of endosseous integration. Int $J$ Prosthodon 1998; 11: 391-401.

5. Inoue T, Matsuzaka K, Yoshinari M, Tanaka T, Abiko Y, Shimono M. Current Dental Implant Research. Dentistry in Japan 2005; 41: 196-213.

6. Inoue T, Matsuzaka K, Yoshinari M, Abiko Y, Shimono M. Implant-bone Tissue Interface. Bull Kanagawa Dent Coll 1999; 27: 132-41.

7. Keller JC, Stanford CM, Wightman, JP, Draughn, RA, Zaharias R Characterizations of titanium implant surfaces. J Biomed Mater Res 1994; 28: 939-46.

8. Kieswetter K, Schwartz Z, Dean DD, Boyan BD. The role of implant surface characteristics in the healing of bone. CRC Crit Rev Oral Biol Med 2000; 7: 329-45.

9. Loesberg WA, Walboomers XF, Bronkhorst EM, van Loon JJ, Jansen JA. The effect of combined simulated microgravity and microgrooved surface topography on fibroblsts. Cell Motil Cytoskeleton 2007; 64: 174-85.

10. Loesberg WA, Walboomers XF, van Loon JJ, Jansen JA. The effect of combined hypergravity and micro-grooved surface topography on the behavior of fibroblasts. Cell Motil Cytoskeleton 2006; 63: 384-94.

11. Matsuzaka K, Yoshinari M, Shimono M, Inoue T. Effects of multi-grooved surfaces on osteoblast-like cells in vitro: Scanning electron microscopic observation and mRNA expression of osteopontin and osteocalcin. J Biomed Mater Res 2004; 68A: 227-34.

12. Nashimoto M, Matsuzaka K, Yoshinari M, Shimono M, Inoue $\mathrm{T}$. The effect of surface pore size on the differentiation of rat bone marrow cells: Morphological observations and expression of bone related protein mRNA. Bull Tokyo Dental Coll 2005; 45: 201-11.

13. Schwartz Z, Boyan BD. Underlying mechanisms at the bone-biomaterial interface. J Cell Biochem 1994; 56: 3407.

14. Shiigai T, Shimono M, Yoshinari M, Matsuzaka K, Inoue $\mathrm{T}$. The effect of substrate pore size on the differentiation of L929 fibroblast cells: Morphological observations and expression of type 1 collagen mRNA. Biomedical Res 2004; 25: 61-8.

15. Swart KM, Keller KC, Wightma JP, Draughn RA, Stanford $\mathrm{CM}$, Michaels CM. Short-term plasma-cleaning treatments enhance in vitro osteoblast attachment to titanium. $J$ Oral Implantol 1992; 18: 130-7.

16. Sykaras N, Iacopino AM, Marker VA, Triplett RG, Woody 
RD. Implant materials, design, and surface topographies: Their effect on osseointegration. A literature review. Int. $J$ Oral Maxllofac Implants 2000; 15: 625-90.

17. Taylor AC. Adhesion of cells to surface. In: Manly RS ed. Adhesion in Biological systems. Academic Press, New York, 1970; 51-71.

18. Vezeau PJ, Koorbusch GF, Draughn RA, Keller JC Effects of multiple sterilization on surface characteristics and in vitro biologic responses to titanium. J Oral Maxillofac Surg 1996; 54: 738-46.

19. Stanford CM, Keller JC, Solursh M. Bone cell expression on titanium surfaces is altered by sterilization treatment. $J$ Dent Res 1994; 73: 1061-71.

20. Cooper LF, Tiffee JC, Griffin J P, Hamano H, Guo Z. Estrogen-induced resistance to osteoblast apoptosis is associated with increased hsp27 expression. J Cell Physiol 2000; 185: 401-7.

21. Lian JB, Stein GS. The developmental stages of osteoblast growth and differentiation exhibit selective responses of genes to growth factors (TGF $\beta 1$ ) and hormones (Vitamin
D and glucocorticoids). J Oral Implantol 1993; 19: 95-105.

22. Denhardt DT, and Guo X. Osteopontin: a protein with diverse functions. Gaseb 1993; J7: 1475-82.

23. Toma CD, Ashr S, Gray ML, Schaffer JL Gerstenfeld LC. Signal transduction of mechanical stimuli is dependent on microfilament integrity; identification of osteopontin as a mechanically induced gene in osteoblasts. J Bone Miner Res 1997; 12: 1626-36.

24. Fujii K, Inoue H. Biology of Bone and Cartilage Application of Basic Science for Practice Medicine. Kanehara, Tokyo, 2002; 25-7.

25. Bilezikian JP, Raisz LG, Rodan GA. Principles of Bone Biology. Academic Press, San Diego, 1996; 77-9.

26. Salter DM, Robb J, Wright MO. Electrophysiological responses of human bone cells to mechanical stimulation; evidence for specific integrin function in mechanotransduction. J Bone Miner Res 1997; 12: 1134-41.

27. Tanaka H. Mechanical stress and bone resorption. Mol Med 2001; 38: 656-60.

Received March 12,2010 Accepted September 27, 2010 